\title{
EVALUATION OF BUD CHIP METHOD TO INCREASE SUGARCANE PRODUCTIVITY (CASE STUDY OF PT PERKEBUNAN NUSANTARA X)
}

\author{
Ahmad Zainuddin*)1, Rudi Wibowo*), and Intan Kartika Setyawati*) \\ *) Agribusiness Study Program, Faculty of Agriculture, University of Jember \\ Jl. Kalimantan 37 Kampus Tegal Boto Jember 68121, Indonesia
}

\begin{abstract}
Bud chip method has proven to improve the productivity of sugarcane and produce more efficient, but still a few farmers who use it. This is due to higher production costs and sugarcane farmers are still not technically skilled. This study aimed to analyze the technical efficiency of sugarcane farming with conventional methods and bud chips in the PTPN X and to identify the factors underlying the farmers to use methods of bud chips in the PTPN X. The number of samples used as many as 31 farmers ( 11 farmers sugarcane bud chip method and 20 sugarcane farmers mule method). This study uses a stochastic frontier production function approach with Stochastic Frontier production function Cobb Douglas and using a logistic regression model. The results showed the value of technical efficiency index sugarcane growers with bud chip method is efficient $(\mathrm{TE}=0.98)$ whereas the sugarcane farmers who use mule systems have not been efficiently categorized (TE= 0.78). Bud chip method has been proven can improve technical efficiency because it can result in higher productivity. The underlying things that make farmers choose the bud chip method are extensive cultivation, education level and ease of sugarcane cultivation with the bud chip method. Therefore, sugarcane productivity in PTPN X can be increased through the use of the bud chip method accompanied by an increase in sugarcane land area and training for farmers.
\end{abstract}

Keywords: technical efficiency, sugarcane farming, bud chip

Abstrak: Metode bud chip terbukti meningkatkan produktivitas tebu dan lebih efisien, namun masih sedikit petani yang menggunakannya. Hal ini dikarenakan biaya produksi yang lebih tinggi dan petani tebu masih belum mahir secara teknis. Penelitian ini bertujuan untuk menganalisis efisiensi teknis usahatani tebu dengan metode konvensional dan bud chip di PTPN X; dan untuk mengidentifikasi faktor-faktor yang mempengaruhi petani untuk menggunakan metode bud chip di PTPN X. Jumlah sampel yang digunakan sebanyak 31 petani (11 petani tebu metode bud chip dan 20 petani metode bagal). Penelitian ini menggunakan pendekatan fungsi produksi stochastic frontier dengan fungsi produksi Stochastic Frontier Cobb Douglas dan menggunakan model regresi logistik. Hasil penelitian menunjukkan nilai indeks efisiensi teknis petani tebu dengan metode bud chip yang efisien $(T E=0,98)$ sedangkan petani tebu yang menggunakan sistem bagal belum dikategorikan efisien $(T E=0,78)$. Metode bud chip telah terbukti dapat meningkatkan efisiensi teknis karena dapat menghasilkan produktivitas yang lebih tinggi. Hal mendasar yang membuat petani memilih metode bud chip adalah luas lahan, tingkat pendidikan dan kemudahan budidaya tebu dengan metode bud chip. Oleh karena itu, produktivitas tebu di PTPN X dapat ditingkatkan melalui penggunaan metode bud chip disertai dengan peningkatan luas lahan tebu dan pelatihan bagi petani.

Kata kunci: efisiensi teknis, usahatani tebu, bud chip

\footnotetext{
${ }^{1}$ Corresponding author:

Email: zainuddin91.faperta@unej.ac.id
} 


\section{INTRODUCTION}

In accordance with the self-sufficiency program, the government has provided investment funds that are used to develop the national sugar industry in terms of both on-farm (cultivation) and off-farm (processing industry or sugar mills) (Sulaiman et al. 2019). The development target of the national sugarcane industry in the first level was cultivation or on-farm, which are the target of increasing production and productivity of sugarcane feedstock. The steps are taken to increase the production and productivity of sugarcane raw materials by increasing the area of sugarcane wherein 271 thousand hectares in 2015 to 357 thousand hectares in 2019 (BUMN, 2018).

Two important conditions faced by the national sugar industry in the field of on-farm. First, the latent problem in the on-farm is limited availability of sugarcane land. The development of the national sugar industry is hampered by the difficulty of obtaining sugarcane fields. Sugarcane fields have not increased significantly and it were increasingly shifting from technical irrigation rice fields to less fertile soil and far from irrigation (Rohmatullo et al. 2009). The shift is caused by landowners tend to plant other crops that is more interesting to farmers because it is more profitable and the land conversion into non-agricultural areas. The growth of sugarcane fields nationally in the last five years have decreased. The national sugarcane area in 2011 amounted to 450,298 ha, but by 2015 the sugarcane field was only 448,169 ha. When compared to sugarcane land in Thailand which reached 1.350.000 ha, the national sugarcane is still very low ((Subiyono, 2014); (BUMN, 2018)). This limited land indirectly affects the production and performance of the national sugar industry. Second, the low productivity of sugarcane also has implications for the decreasing performance of the national sugar industry. The productivity of sugarcane in the last five years (20152019 ) is around 49.9 tons per ha -56.10 tons per ha (Pusdatin, 2019). The figure is still far from reaching the world's sugarcane productivity 89-90 tons per ha. Sugarcane productivity is determined by soil fertility, labor availability, irrigation systems, the application of technology,changes in extreme weather, mismatches between sugarcane varieties and available agricultural locations, and the unavailability of workers who can apply appropriate sugarcane cultivation techniques.
One of the efforts to increase sugar cane production is by using the bud chip method. The bud chip method is applied by taking the bud eye of the cane, then nursed in a nursery with special treatment. Eye buds are from selected sugar cane, then sterilized in 51 degrees for 30 minutes. After that, new buds are planted in a nursery for 10 days. If it grows, the seedlings will be planted in polybags and left for up to three months. Once ready to plant, new seedlings are transferred to sugarcane fields. The method of bud chip can increase the production of sugarcane because the sugarcane produced will grow uniformly, both high and the maturity level, The bud chip method can also suppress the use of seeds and seedlings in the process of planting sugar cane.

The bud chip method can increase the productivity of sugarcane to 136 tons per hectare (in Colombia). This figure is still much higher than the level of sugarcane productivity in East Java,Indonesia which is only about 80 tons per ha. The use of the bud chip method is much more efficient where the nursery with the old method would require around 48,000 eye seedlings per hectare, whereas the bud chip method requires only 9,000 to 12,000 eye seedling per hectare. Although it is more efficient in the use of seeds and can increase the productivity of sugarcane, but few farmers who use the method. This could be due to the cost of production by this method is higher and the bud chip technique requires expertise so that the sugarcane farmer still not technically skilled yet. Thus, sugarcane farming using the bud chip method has the potential to be developed through farming efficiency.

According to (Coelli et al. 1998) there are three sources of productivity growth, namely technological change, improvement of technical efficiency, and change in efficiency scale. The application of the bud chip in sugarcane farming refers to the source of productivity growth, including efforts to increase productivity through technological change, which is then expected to improve the technical efficiency of rice farming, so that the goal of applying the bud chip technology in the form of increased production and productivity of rice is achieved. Technical efficiency studies in terms of productivity or output are used to see the ability of producers to achieve maximum production (Etwire et al. 2013; Ningsih, 2014). The study shows the inability of farmers to achieve maximum production is influenced by socioeconomic factors and farmer characteristics. 
Research on farming efficiency (technical efficiency, allocative, and economic) have been carried out in various regions in Indonesia and the world. The range of technical efficiency, allocative and economic in various studies are relatively diverse, but Bakhsh et al. (2006); Kea et al. (2016); Singh et al. (2018); Supaporn, (2015); Mutenheri et al. (2017) found that the level of efficiency of farmers amounted to 0.70 can be said to have efficient, while Coelli et al. (1998) stated that the level of farmer efficiency of 0.80 can be said to have been efficient. Sugarcane production efficiency study in East Java was conducted by Susilowati and Tinaprilla, (2012); Purnamasari et al. (2018). The results showed the value of technical efficiency index cane farming in East Java categorized yet efficient with an average efficiency of 0.65 (Standard TE $=0.8$ ). Research Asmarantaka et al. (2012) also analyze the technical efficiency of sugarcane in Lampung. Based on the analysis of technical efficiency obtained an average yield efficiency score of 0.93 , while 20 respondents $(55.56 \%)$ already had a score of 1 indicating that the sugarcane farming is efficient.

Research Asmara and Lewis (2009) stated that firstly, the factors were significant at the level of the production function frontier sugarcane farming in the study area is the area of land and labor. While phonska fertilizer, ZA fertilizer, and urea fertilizer have no significant effect on sugarcane production. Secondly, the level of technical efficiency of input use is achieved most farmers (50\%) on sugarcane farming is high, which is $>90 \%$ of potential production, it indicates that there are $10 \%$ of the potential that can be achieved by farmers. While the average technical efficiency achieved by sugarcane farmers in Krajan Hamlet, Banjarejo Village, Pagelaran District, Malang Regency is $94.36 \%$. Farmers as individual decision-makers always influenced by the availability of household resources and also by its social relations, that is decisions of society will affect individual decisions. Besides, cultivation behavior also interconnected with social behavior, culture, economy, and behavior of people's lives rural. Form of interaction between these factors ultimately a decisive factor in decision making by farmers (Suek, 1994; Gilbert and Norman, 1980). Research on the potential of sugar cane farming by bud chip method ever done by Samant (2017); Mishra (2019). The results showed that sugarcane farming using the bud chip method was able to produce products of 129.2 ton per ha or able to produce $39,7 \%$ more than farmers with the conventional method. Previous studies discussed more about the efficiency of sugarcane farming and productivity produced by non-bud chips and bud chips.
Novelty of this study is the comparison of technical efficiency (farmers using bud chips and conventional method) and decision factors of farmers using bud chips in PTPN X.

\section{METHODS}

This research was carried out in the province of East Java especially in the working area of PTPN X. This location was selected through purposive sampling method because East Java Province is the largest production center in Indonesia and PT PTPN X is a StateOwned Enterprises which has the largest productivity of sugarcane and sugar in East Java. The research was scheduled to take place from June to October 2018.

The relevant data collected for this research comprised primary data. The primary data were gathered through the interview with the respondents. The sample consists of a number of farmers and was drawn in a purposive manner because there was no available sampling frame on site. In so doing, the criterion used in selecting farmers to be the respondents in this research were the farmers who grew sugarcane during the same planting season. The number of farmers sampled for this research is 31 that consisted of 11 farmers who cultivate sugarcane with the bud chip method and 20 farmers using the conventional method.

This research employed a production function model known as the stochastic frontier to perform functional analysis on the sugarcane production in question. Factors predicted to be influential in the production process were farm size, seeds, inorganic fertilizers, pesticides, and labors. By including five independent variables into the frontier equation, the predictive model of the stochastic frontier production function for the studied sugarcane farming is as follows (Coelli, Prasada, \& Battese, 1998):

$$
\begin{aligned}
\operatorname{Ln} Y= & \ln \beta_{0}+\beta_{1} \ln X_{1}+\beta_{2} \ln X_{2}+\beta_{3} \ln X_{3}+\beta_{4} \ln X_{4}+\beta_{5} \ln X_{5} \\
& +\left(v_{i}-u_{i}\right)
\end{aligned}
$$

Where: $\mathrm{Y}$ (sugarcane production $(\mathrm{kg})$ ); $\mathrm{X}_{1}$ (the size of sugarcane farmland (ha)); $\mathrm{X}_{2}$ (sugarcane seeds (Tons)); $\mathrm{X}_{3}$ (inorganic fertilizer (Tons)); $\mathrm{X}_{4}$ (pesticide (liters)); $\mathrm{X}_{5}$ (labor (HOK)); $\beta_{0}$ (intercept); $\beta_{\mathrm{i}}$ (estimated parameter); $\mathrm{v}_{\mathrm{i}}-\mathrm{u}_{\mathrm{i}}$ (technical inefficiency effect in the model). The expected parameter symbols and values: $\beta_{1}, \beta_{2}, \beta_{3}, \beta_{4}$, $\beta_{5}>0$. 
While the level of technical efficiency is analyzed using stochastic frontier model. The analysis of technical efficiency can be executed using this following equation (Coelli, Prasada, \& Battese, 1998):

$$
\mathrm{TEi}=\exp (-\mathrm{E}[\mathrm{ui} \mid \in \mathrm{i}]) ; \mathrm{i}=1,2, \ldots, \mathrm{n}
$$

in which Tei denotes the technical efficiency of farmer i, exp (-E[ui|ei]) represents the expected value (mean) of ui with condition set by $\epsilon i$. The value of technical efficiency is within $0 \leq \mathrm{Tei} \leq 1$. This value is inversely proportional to the value of the technical inefficiency effect and is used only on function with certain quantity of output and input (cross-section data).

The method employed in this research in performing an analysis on the factors impacting on technical inefficiency refers to the model proposed by Coelli et al. (1998). Variable ui used in assessing the technical inefficiency effect is assumed to be independent variable and its distribution is truncated normal with $\mathrm{N}$ $(\mu \mathrm{i}, \sigma 2)$ (Stevenson, 1980; Greene, 1993).

The value of distribution parameter ( $\mu \mathrm{i})$ of technical inefficiency effect is defined through this following equation:

$$
\mathrm{U}_{\mathrm{i}}=\delta_{0}+\delta_{1} \mathrm{Z}_{1}+\delta_{2} \mathrm{Z}_{2}+\delta_{3} \mathrm{Z}_{3}+\delta_{4} \mathrm{Z}_{4}+\omega_{1} \mathrm{D}_{1}
$$

where $\mathrm{Ui}=$ technical inefficiency effect; $\mathrm{Z1}=$ the age of the sugarcane farmer (year); Z2 =the farmer's level of education (year); $\mathrm{Z3}$ = the number of family members (person); Z4 =the farmer's experience (year); D1 = dummy variable of bud chip technology (bud chip technology $=1$ and conventional technology $=0$ ). The expected parameter symbols and values: $\delta 0, \delta 1>0$ and $\delta 2, \delta 3, \delta 4, \omega 1<0$.

Logit analysis is used to determine the factors that influence the decision of farmers to choose the bud chip technology or the conventional method in conducting sugarcane farming. The logit model has been estimated as follows:

$$
Y(x)=\ln \left(\frac{y(x)}{1-y(x)}\right)=\beta_{0}+\beta_{1} X_{1}+\beta_{2} X_{2}+\beta_{3} X_{3}+\beta_{4} X_{4}+\beta_{5} D_{1}+\beta_{6} I
$$

Where: Y (sugarcane farmers decision (Dummy Variable) ( $0=$ does not use the bud chip technology); 1 (using the bud chip technology); $\mathrm{B}\left(\right.$ Constant); $\mathrm{X}_{1}$ (Farm size (ha)); $X_{2}$ (Farmer's age (year)); $X_{3}$ (the farmer's level of education (year)); $\mathrm{X}_{4}$ (the farmer's experience (year)); $\mathrm{D}_{1}$ (farm cost (dummy variables) $(0=$ expensive, $1=$ cheap) $) ; \mathrm{D}_{2}$ (dummy variable about application of the bud chip technology $(0=$ difficult, $1=$ easy)).

\section{RESULTS}

\section{Respondents' Characteristics}

The respondents involved in this research were 31 sugarcane farmers consisted of 11 farmers who cultivate sugarcane with the bud chip method and 20 farmers using the conventional method. The characteristics of the farmer respondents considered significant to take into account include those related to age, educational background, farm size, and the farmer's experience in sugarcane farming. A farmer's age is assumed as one of the factors affecting the farmer's performance in managing farming activities. Older farmers are generally less responsive to the advancement of technological inventions. As shown in Table 1, most of the farmers' ages ranged between 30 and 50 years old. It implies that the respondents were in their productive period during which they could make a good performance in managing their sugarcane farming undertakings (Table 1). A comparative test using t-test showed that there is no age difference between farmers who use bud chips and non-bud chips.

The level of education of farmers in this research is formal education. Based on the level of education, sugarcane farmers using bud chip technology have a relatively higher level of education compared to farmers using conventional method, where most of the farmers applying bud chip technology are graduates of bachelor degree and there are even $18 \%$ who are postgraduates. While farmers who use conventional systems have a relatively lower level of education. Table 1 shows that most of the education of farmers using the conventional system is from junior to senior high school, although there are $25 \%$ who have undergraduate education. The level of education is closely related to the use of technology and the adoption of agricultural innovation. Higher education is expected to increase the knowledge and skills of sugarcane farmers. This is consistent with the results of the t-test which showed a significant difference in the level of education between two groups of farmers. 
The other factor mentioned in the table is the farmer's experience in sugarcane farming. The extent of a farmer's experience in dealing with sugarcane farming activities is considered one of the influential factors in the extent of his achievement in sugarcane farming. In terms of sugarcane farming experience, farmers using bud chip technology have lower farming experience compared to farmers using conventional technology. The t-test results showed that there was a significant difference $(90 \%$ confidence level) between the experience of farmers using the bud chip method and farmers using the conventional method.

Land area is also a consideration of farmers to apply bud chip technology or not. Sugarcane cultivation using bud chip technology requires more labor and requires special attention, so it is more appropriate to be planted on a relatively more narrow land. It is shown in Table 1 that most sugarcane farmers using bud chip and conventional technology have a relatively wide area of about 11-20 ha. This is consistent with the t-test which states that there is no difference between the land area of the two groups.

\section{Sugarcane Function Production Prediction Using MLE Method}

The results of estimation using stochastic production function (Technical Efficiency Effect Model) through the incorporation of the observed inefficiency factor were mostly in line with what was expected. Based on the resulted prediction as shown in Table 2, the value of log-likelihood MLE (25.232) is higher than the value of log-likelihood OLS (12.139), verifying that the adoption of production function through the application of MLE method is well-suited to the condition of the studied area. Gamma value is a contribution of the technical efficiency to the total residual effect. The resulted gamma value is 0.776 and shows a real influence at $\alpha 1 \%$. It indicates that $77.6 \%$ of the varied level of sugarcane production among the respondents was caused by technical efficiency factor whereas the rest portion, $22.4 \%$, was related to stochastic effects. It follows that the dominant cause of differences in sugarcane production in the working area of PTPN X was inefficiency variable $\left(\mathrm{u}_{\mathrm{i}}\right)$ instead of noise variable $\left(v_{\mathrm{i}}\right)$. This model has been proven reasonably suitable to the gamma value which is higher than 0.50 .

Table 1. Farmer respondents' characteristic

\begin{tabular}{|c|c|c|c|c|c|c|}
\hline \multirow{2}{*}{$\begin{array}{l}\text { The } \\
\text { characteristic }\end{array}$} & \multirow{2}{*}{ Category } & \multicolumn{2}{|c|}{$\begin{array}{l}\text { Sugarcane farmers with } \\
\text { the bud chip method }\end{array}$} & \multicolumn{2}{|c|}{$\begin{array}{l}\text { Sugarcane farmers with } \\
\text { the conventional method }\end{array}$} & \multirow{2}{*}{ T-Test } \\
\hline & & $\begin{array}{c}\text { Frequency } \\
\text { (person) }\end{array}$ & $\begin{array}{c}\text { Percentage } \\
(\%)\end{array}$ & $\begin{array}{l}\text { Frequency } \\
\text { (person) }\end{array}$ & $\begin{array}{c}\text { Percentage } \\
(\%)\end{array}$ & \\
\hline \multirow[t]{3}{*}{ Farmer's age (years) } & $31-40$ & 2 & 18.18 & 6 & 30 & \multirow{3}{*}{$\begin{array}{l}0.7500 \\
(0.459)\end{array}$} \\
\hline & $41-50$ & 5 & 45.46 & 9 & 45 & \\
\hline & $51-60$ & 4 & 36.36 & 5 & 25 & \\
\hline \multirow{5}{*}{$\begin{array}{l}\text { Educational } \\
\text { attainment }\end{array}$} & Elementary school & - & - & 3 & 15 & \multirow{5}{*}{$\begin{array}{l}4.7292^{\mathrm{a}} \\
(0.000)\end{array}$} \\
\hline & Junior High school & - & - & 6 & 30 & \\
\hline & Senior High School & 2 & 18.18 & 6 & 30 & \\
\hline & Under graduate (S1) & 7 & 63.64 & 5 & 25 & \\
\hline & Post Graduate (S2) & 2 & 18.18 & - & - & \\
\hline \multirow{4}{*}{$\begin{array}{l}\text { Farmer's } \\
\text { Experience (Years) }\end{array}$} & $1-10$ & 5 & 45.46 & 3 & 15 & \multirow{4}{*}{$\begin{array}{l}1.7116^{c} \\
(0.097)\end{array}$} \\
\hline & $11-20$ & 3 & 27.27 & 9 & 45 & \\
\hline & $21-30$ & 1 & 9.09 & 6 & 30 & \\
\hline & $>30$ & 2 & 18.18 & 2 & 10 & \\
\hline \multirow[t]{4}{*}{ Farm size (Ha) } & $1-10$ & 3 & 27.27 & 4 & 20 & \multirow{4}{*}{$\begin{array}{l}1.1217 \\
(0.270)\end{array}$} \\
\hline & $11-20$ & 4 & 37.37 & 9 & 45 & \\
\hline & $20-30$ & 2 & 18.18 & 4 & 20 & \\
\hline & $>30$ & 2 & 18.18 & 3 & 15 & \\
\hline
\end{tabular}

Notes: a is real at $\alpha=1 \%, \mathrm{~b}$ is real at $\alpha=5 \%$, c is real at $\alpha=10 \%$ 
All of the predicted variables provide a coefficient with positive value except the variable amount of labor. All the five variables predicted to be relevant, those with a significant impact on the sugarcane farmers' frontier production are farm size, seed, and labor. Those variables still have the potential to generate an increase in production at these real levels $\alpha 1 \%$.

The prediction parameter on the SPF (Stochastic Production Function) presented above shows the elasticity values of frontier production for the inputs being used. It is defined as such for the reason that in the Cobb-Douglas function, the resulted coefficient is the superscript of the Cobb-Douglas function which indicates the elasticity value of production for each of the input being used. The sum of coefficients indicates a return to scale and in this case, the sum of the production function coefficients in Table 2 is 1.629. This figure reveals that Cobb-Douglass production function with the application of MLE method is in a state of increasing return to scale.

The results of estimation in Table 2 explain that the production elasticity for farm size variable is found having a tangible or real influence on the sugarcane production at $\alpha=1 \%$ in extent and at 1.629 in value. This value describes that $1 \%$ increase in farm size (ceteris paribus) can still enhance sugarcane production by $1.629 \%$. Compared to the other variables, the farm size variable is the most responsive one since it retains the highest coefficient value. The average size of the existing sugarcane farmlands in the working area of PTPN X is 20 ha. This quantity is relatively large. It follows that if PTPN X wants to improve their sugarcane production, they need to think about expanding their land. This finding is in line with the findings that resulted in the researches conducted by (Susilowati and Tinaprilla, 2012) which suggest that farm size has a positive and real influence on sugarcane production.

The other inputs such as the variety of seeds do not show elasticity, which means the increase in those inputs could only lead to a relatively small amount of increase in production. On the other hand, the production elasticity of seed is found having a real influence on the sugarcane production at 0.045 in value. This value indicates that $1 \%$ increase in seed (other variables assumed to be constant) can still cause an increase in sugarcane production in PTPN X by $0.045 \%$.

Labor has a significant effect on cane production with the coefficient of -0.297 . This means that sugarcane production can be increased by reducing the amount of labor used. Sugarcane farming is classified as a labor-intensive farming system, but the use of labor in sugarcane farming in PTPN X work area is high. This can be seen from the amount of labor used in one hectare is $157 \mathrm{HOK}$. The value is categorized high when compared with (Asmarantaka et al. 2012), which shows the amount of labor used is only 142 $\mathrm{HOK} /$ hectare. Therefore, to increase the production of sugarcane at PTPN X, there is a need to reduce the number of workers, especially labor for the supply of seeds and harvest which have a higher proportion than the other parts.

Table 2. The results of the estimation of sugarcane production function parameters

\begin{tabular}{|c|c|c|c|}
\hline Variable & Coefficient & Standard Error & T-ratio \\
\hline Constant & $13.436^{\mathrm{a}}$ & 1.322 & 10.155 \\
\hline Farm Size (X1) & $1.245^{\mathrm{a}}$ & 0.280 & 4.443 \\
\hline Seed (X2) & $0.045^{\mathrm{a}}$ & 0.088 & 5.123 \\
\hline Inorganic fertilizer(X3) & 0.012 & 0.061 & 0.201 \\
\hline Pesticide (X4) & 0.030 & 0.046 & 0.638 \\
\hline Labour (X5) & $-0.297^{\mathrm{a}}$ & 0.250 & -3.184 \\
\hline Sigma-squared & 0.013 & & \\
\hline Gamma & 0.776 & & \\
\hline Log-likelihood function OLS & 12.139 & & \\
\hline Log likelihood function MLE & 25.232 & & \\
\hline LR test of the one $=$ sided error & 26,186 & & \\
\hline
\end{tabular}

Notes: ais real at $\alpha=1 \%, \mathrm{~b}$ is real at $\alpha=5 \%$, c is real at $\alpha=10 \%$ 


\section{Technical Efficiency in Sugarcane Farming}

A farm is said to be technically efficient if it can produce many outputs using fewer inputs or can produce the maximum output from a given input. The level of technical efficiency in this study was analyzed using the Cobb Douglass Stochastic Frontier production function with the maximum likelihood estimate (MLE) estimation method. Technical efficiency in this research is divided into two, namely the distribution of technical efficiency for farmers who do cultivation by using bud chip technology and distribution of technical efficiency for farmers using the conventional systems. If the efficiency value is used, the farming efficiency index $>$ 0.8 is considered to have a good level of efficiency and an efficiency index of $<0.8$ is said to have an inadequate farm efficiency (Coelli et al. 1998), farmers' distribution based on the efficiency level of both farmers using bud chip technology and conventional method is described as follows.

The results (Table 3) show that the average technical efficiency of sugarcane farming using the bud chip method is higher than sugarcane farming with conventional technology. Sugarcane farming with the bud chip technology has an average technical efficiency of 0.988 , with a minimum technical efficiency rating of 0.976 and a maximum technical efficiency rating of 0.993 . The technical efficiency index value is categorized as efficient since the value is more than 0.80 as the efficient limit (Coelli et al. 1998). If referring to this category, sugarcane farming using bud chip technology is technically efficient. All farmers who using the bud chips are technically efficient because the technical efficiency level of all farmers is more than 0.90. Although many farmers have argued that bud chips farming requires intensive labor and intensive watering, but farmers claim that the production yields are also higher. this is because the sugarcane crop production by using the bud chip can produce as many as 8 to 12 tillers. while conventional technology can only produce 5 tillers in its production process.

Unlike sugarcane farmers applying bud chip technology, sugarcane farmers using conventional technology have an average technical efficiency rating of 0.782 , with a minimum technical efficiency rating of 0.644 and the highest technical efficiency value is 0.950 . Based on the above categories, sugarcane farmers with conventional systems are categorized as inefficient. Farmers with conventional systems have an average productivity of $10.93 \mathrm{Tons} /$ hectare, which is lower than the average productivity of sugarcane farmers using bud chip technology (15.14 Tons/hectare). The value indicates that sugarcane farming using bud chip method can produce larger production, although it requires bigger cost and labor-intensive. These results indicate that cane farming using well-managed bud chip technology will produce output near the maximum limit (frontier). Therefore, in this research will be discussed about the factors underlying sugarcane farmers in the work area of PTPN X to use bud chip technology.

Table 3. The Distribution of the results of analysis on the technical efficiencies of sugarcane farming

\begin{tabular}{lcccc}
\hline Efficiency & \multicolumn{2}{c}{ Bud chip Method } & \multicolumn{2}{c}{ Conventional method } \\
\cline { 2 - 5 } Distribution & Frequency (person) & Percent (\%) & Frequency (person) & Percent (\%) \\
\hline$<0.60$ & 0 & 0 & 0 & 0 \\
$0.61-0.70$ & 0 & 0 & 4 & 20 \\
$0.71-0.80$ & 0 & 0 & 10 & 50 \\
$0.81-0.90$ & 0 & 0 & 3 & 15 \\
$>0.91$ & 11 & 100 & 3 & 15 \\
Total & 11 & 100 & 20 & \\
\hline Average value & 0.9880 & & 0.7819 & \\
Maximum value & 0.9933 & & 0.9494 & \\
Minimum value & 0.9756 & & 0.6435 & \\
\hline
\end{tabular}


Factors Affecting the Technical Inefficiency of Sugarcane Farming

The variables functioning as the determinants of technical efficiency in sugarcane farming in PTPN X were analyzed using the inefficiency effect model of a stochastic frontier production function. As mentioned earlier, there are five determining variables for the technical inefficiency of sugarcane farming studied in this research. They are farmer's educational level, farmer's age, farmer's experience, the number of family members, dummy variables about ease of application of bud chip technology (Table 4).

The age variable shows the real influence on inefficiency as demonstrated by the positive value of its coefficient (0.008). It implies that the older the farmer is, the higher the inefficiency will be. It suggests that younger farmers (less than 50) tend to develop a more efficient farming industry. The obtained empirical data have shown that most of the respondents were in their relatively advanced age (40-50 years old on average). Regarding this condition, those farmers need to pass down their farming industry to the next generation of sugarcane farmers. Unfortunately, most of their children were not encouraged to continue their parents' farming industry and most of the farmer parents had not made serious efforts in preparing or training their children in sugarcane farming. They preferred to put their children through higher education and to allow them to have a job other than running a farm. This finding is in line with those findings in the researches conducted by Ojo (2003); Vilano and Fleming (2006); Okaye et al. (2008); Ningsih et al. (2015); Orewa and Izekor (2012) which show that age has negative influence on technical inefficiency.
The educational level variable has a negative and significant influence on the real level of $1 \%$. This means that higher education of farmers will reduce technical inefficiency or improve technical efficiency. Farmer education in the research area shows that most farmers have high school and bachelor education. Farmers in the research area already have a relatively high education, to be able to improve technical efficiency.

The variable number of family members has a negative sign, which implies that an increasing number of family members will decrease technical inefficiency or improve technical efficiency. This is because family members will assist farmers in managing cane farming. Besides, the number of family members will be taken into account as the workforce that comes from the family so that it will reduce the use of labor outside the family. Circumstances in the field indicate that all labor used is labor that comes from outside the family. In the estimation of production function also shows the amount of labor used is excessive so that family members can assist farmers in managing cane farming.

Another variable that determines the technical inefficiency of sugarcane farming is the dummy variable of ease of sugarcane cultivation by using bud chip technology. this variable has a real effect with negative coefficients. The estimation results show that sugarcane farming with bud chip technology will reduce technical inefficiency or improve technical efficiency rather than using old systems or conventional systems. This is because the sugarcane cultivation system with the bud chip method can produce higher productivity than the conventional system so that this bud chip technology will reduce the level of technical efficiency.

Table 4. Factors affecting the technical inefficiency of sugarcane farming

\begin{tabular}{lccc}
\hline Variable & Coefficient & Standard Error & t-rasio \\
\hline Constant & $1.332^{\mathrm{a}}$ & 0.483 & 2.756 \\
Age $\left(\mathrm{Z}_{1}\right)$ & $0.008^{\mathrm{b}}$ & 0.005 & 2.502 \\
Educational Level $\left(\mathrm{Z}_{2}\right)$ & $-0.031^{\mathrm{a}}$ & 0.018 & -3.736 \\
Experience $\left(\mathrm{Z}_{3}\right)$ & 0.007 & 0.004 & 1.681 \\
The number of family members $\left(\mathrm{Z}_{4}\right)$ & $-0.120^{\mathrm{c}}$ & 0.060 & -2.000 \\
Dummy the bud chip application $\left(\mathrm{D}_{1}\right)$ & $-0.391^{\mathrm{a}}$ & 0.394 & -4.918 \\
\hline
\end{tabular}

Notes: a is real at $\alpha=1 \%$. b is real at $\alpha=5 \%$. c is real at $\alpha=10 \%$ 


\section{Factors Underlying Farmers Using Bud chip Technology}

Logit analysis is used to determine the factors that influence the farmer's decision to choose the bud chip method or mule method in sugarcane farming. Variable responses to this analysis are categories form, where farmers are using bud chip rated 1 and farmers who use conventional method rated 0 . Based on previous research and conditions in the field, there are six independent variables suspected to affect the farmers' decision using the bud chip method or mule method in sugarcane farming. Sixth independent variables were the age of farmers, the educational level, the experience of farming, land, farming costs and ease of cultivation. The accuracy model can be seen by used the Negelkerke $\mathrm{R}$ Square value is equal to 0.760 . This value indicates that the ability of independent variables in explaining the dependent variable is equal to 76 percent while the remaining $24 \%$ is made clear by other variables outside the model. The significance of the model was tested using Hosmer-Lemeshow (HL). Of Hosmer and Lemeshow test results were also obtained chi-square value amounted to 6,440 with a significance value of 0 , 598. This value is greater than 0.05 indicating that at a confidence level of 95 percent, it can be believed that the logit regression model used has been sufficiently able to explain the farmer's decision in using the sugarcane cultivation method.

The results of the logistic regression model analysis showed that the trust level $85 \%(\alpha=15 \%)$, there are three variables which were a significant effect on farmer's decision to choose the method of cultivation of sugarcane. The variable is the level of education, land use, and ease of cultivation dummy variables. While the variable age of farmers, the experience of farming and the cost of farming has no significant effect.

The level of education has a significant effect on the $85 \%$ confidence level $(\alpha=15 \%)$ to the decision of farmers using the bud chip technology. The education level of the farmers has a positive coefficient, this means that the chances of farmers using the bud chip technology are positively associated with the education of farmers, the higher education of farmers, farmers' possibility of using the bud chip technology will be higher. The odd ratio value of the variable level of education of farmers amounted to 1,326, which means that any increase in the level of education in one year the probability of farmers using the bud chip technology amounting to 1,326 times (ceteris paribus). Farmer education will determine the level of technology adoption that will be done by the farmers so that higher education will be easier to apply the technology of bud chips in sugarcane farming. It is also in accordance with the characteristics of the farmers who showed that the level of education of farmers that using bud chip higher than the education of farmers who using conventional system or mule, where the average farmer who applies the system of bud chips has educational levels S1 through S2 with an average education for 16 years. Meanwhile, farmers who implement the mules' system have an average education level of high school with an average of formal education for 11.15 years. Factors underlying farmers using bud chip technology in Table 5 .

The variable land area has a significance value of 0.128 so that these variables have a significant influence on the decision of the sugarcane farmer to use the bud chips technology or not. Variable of land area has a positive coefficient, it means the probability of the farmer to use bud chip technology is positively associated with the land area, so the greater land area owned by farmers the possibility of using technology sugarcane bud chip will be even greater. The odd ratio value of the variable the land area amounts to 1,035 which means that any increase in land area of 1 hectare will increase the probability of farmers using the technology bud chip of 1.035 times (ceteris paribus). Increased use of bud chip technology which will increase with the land area due to the use of bud chip technology would be more efficient if applied in a relatively wide area. This is related to the use of labor-intensive and intensive irrigation which is needed in cultivation using bud chip technology.

The average farmer who uses bud chip technology has a land area of 31.9 hectares, while farmers use mule technology has a land area average of 20.8 hectares. This suggests that farmers who use the bud chip technology have a broader area compared to farmers using mules system. Farmers who own narrower land areas have the trend to still use the permanent cropping pattern which already used previously, they use the mule method because using bud chip is complicated and no efficient. Generally, farmers who have small land area has a capital of farming are not too great, so the probability to use bud chips technology is smaller because the use of the bud chip is more labor-intensive. An expanse of land area, the use of bud chip method 
will be more efficient because in terms of financing the purchase of seeds or making seeds and irrigation will be more efficient.

In addition to educational level and land area, ease of cultivation factors also influence the decisions of farmers to use bud chip technology. Ease of cultivation is a dummy variable ( $0=$ method bud chip is difficult to apply; $1=$ method of bud chips is easy to implement). Ease of cultivation variables significant at the 95\% confidence level $(\alpha=5 \%)$. The logit regression coefficient of -4.655 and exp (B) of 0,010 , it means the more difficult sugarcane farming use bud chip method, it will reduce the use of bud chip methods itself or will improve farmers' decision not to use the bud chips amounted to 0,010 , assuming other variables in a constant state. The use of bud chips technology is considered to still quite difficult because the breeding process requires special treatment such as sugarcane buds soaking in warm water or it can be said breeding technique that is more complicated than the old method. Sugarcane farming using the bud chip method also requires intensive labor and more intensive treatment plants compared with mules system, causing the cost incurred also greater. Furthermore when using the bud chips system also require more intensive irrigation so that the farmers considered to be less efficient and relatively difficult to use even though their products are higher than the mule system.
The advantage of the bud chip method is when planted will produce seed buds that are the same in size and its ripe so will produce in a much higher rendement, but its weakness is the method of bud chips require intensive care and irrigation to produce high productivity. Therefore, to improve the implementation of bud chips in the PTPN X required training and intensive assistance from the sugar mills to use bud chips as well as need nursery assistants and capital support so farmers can use bud chips technology which is now becoming abandoned because it considered will increase production cost. In addition, to increase the use of bud chip technology can be directed to the land area which irrigated technically so it is easy to use because it can conduct intensive irrigation.

\section{Managerial Implications}

Based on the result, to improve the implementation of bud chip method in PTPN X required training and intensive assistance from the sugar mill as well as from centers of research and development for use bud chip as well as the need for capital to enable farmers to use bud chips technology are now becoming abandoned because they will increase the cost of production. In addition, the increased production of sugarcane in the region of PTPN X can be achieved through increased use of bud chip technology primarily for areas with land use criteria of the technical irrigation system so it is easy to apply because it can perform intensive irrigation and reduce production costs.

Table 5. Factors underlying farmers using bud chip technology

\begin{tabular}{lccccc}
\hline Variables & $\mathrm{B}$ & S.E. & Wald & Sig. & Exp. (B) \\
\hline Age of farmers & 0.056 & 0.148 & 0.143 & 0.705 & 1.058 \\
Level of education & $0.282 \mathrm{~b}$ & 0.235 & 1,440 & 0.130 & 1,326 \\
Farming experience & $-0,045$ & 0.109 & 0.169 & 0.681 & 0.956 \\
Land area & $0.35 \mathrm{~b}$ & 0.029 & 1,450 & 0.128 & 1.035 \\
Costs of farming & $-0,701$ & 1,726 & 0.165 & 0.685 & 0.496 \\
Ease of cultivation & $-4,655 \mathrm{a}$ & 2,360 & 3.891 & 0.049 & 0.010 \\
Constant & $-5,493$ & 5,053 & 1.182 & 0.277 & 0.004 \\
\hline
\end{tabular}

Description: anoticeable at the level of $\alpha=5 \%$, ${ }^{b}$ real at level $\alpha=15 \%$ 


\section{CONCLUSIONS AND RECOMMENDATIONS}

\section{Conclusions}

The land area of sugarcane has the most responsive impact onproduction. If PTPN X wants to increase the production of sugarcane, then the variable land area should be a major concern. The amount of seed used has a positive influence on the production of sugarcane. While the variable of labor has a negative sign to the production of sugarcane, so the increase in sugarcane production in PTPN X can be achieved with the reduction of labor, especially labor for the provision of seeds and crops have a higher proportion than the other part. There needs a more intensive development of the sugar factory or institution to farmers so that farmers do cultivation and management of production input use properly so that it can increase production.

Generally, the model used can show both the production function and the efficiency of bud chip technology in PTPN X. The technical efficiency index value of farmers using bud chip technology is categorized efficiency while the farmers who implement the mule systems are not efficient yet. This is because farmers with mule system have average productivity of 10,93 Tons/ hectare, which is lower than the average productivity of sugarcane farmers with thebud chip method of 15,14 Tons/hectare. Although sugarcane farming with the bud chip method requires greater cost and labor, but the result of production is also larger. Of the five variables suspected to affect the technical inefficiency of sugarcane farming, on the 85 percent confidence level, four variables significantly affect the inefficiency such as variable age, education level, number of family members, and also the use of bud chip technology. While the experience variable of farming does not affect the technical inefficiency of sugarcane farming.

\section{Recommendations}

Sugarcane farmer decisions in using bud chip technology are based on factors such as level of education, land area and ease of bud chips application. Farmer education will determine the level of technology adoption that will be done by the farmers, so the higher education, the easier to use the bud chip technology in sugarcane farming. Increased use of bud chip technology which will increase with the land area due to the use of bud chip technology would be more efficient if applied in a relatively wide area. Generally, farmers who have small land area has a capital of farming are not too great, so the probability to use bud chip technology is smaller because the use of bud chip is more labor-intensive. The use of bud chip method will be more efficient because in terms of financing the purchase of seeds or making seeds and irrigation will be more efficient. The use of the bud chips technology is considered to still quite difficult because the breeding process requires special treatment such as sugarcane buds soaking in warm water or it can be said breeding technique that is more complicated than the old method. Sugarcane farming using the bud chip method also requires intensive labor and more intensive treatment plants compared with the mules system, causing the cost incurred also greater. Furthermore when using the bud chips system also require more intensive irrigation so that the farmers considered to be less efficient and relatively difficult to use even though their products are higher than the mule system.

\section{REFERENCES}

Asmara R, Lewis S. 2009. Technical efficiency analysis of farm sugarcane. HABITAT 20(1): 1-10.

Asmarantaka R, Baga L, Suprehatin, Maryono. 2012. Analysis of Farming Sugarcane Farmers in Lampung. Dalam R. Asmarantaka, L. Baga, Suprehatin, \& Maryono, Economy Sugar (hal. 61-76). Jakarta: PT Gramedia.

Bakhsh K, Ahmad B, Hassan S. 2006. Increasing food security through technical efficiency. Asian Journal of Plant Sciences 5(6): 970-976. https:// doi.org/10.3923/ajps.2006.970.976.

BUMN. 2018. National Sugarcane Commodity Road Map. Jakarta: BUMN.

Coelli T, Prasada RD, Battese G. 1998. An Introduction to Efficiency and Productivity Analysis. Boston, London: Kluwer Academic Publishers. https:// doi.org/10.1007/978-1-4615-5493-6.

Etwire P, Martey E, Dogbe W. 2013. Technical efficiency of soybean farms and its determinants in saboba and chereponi districts of northern ghana: a stochastic frontier approch. Sustainable Agriculture Research 2(6): 106-116. https://doi. org/10.5539/sar.v2n4p106.

Gilbert E, Norman D. 1980. A General Overview of Farming Systems Research in Reading in Farming Systems Research and Development. United State: Westview Press. 
Greene H. 1993. Maximum likelihood estimation of stochastic frontier production models. Journal of Economics 18(2): 285-238. https://doi. org/10.1016/0304-4076(82)90043-4.

Kea S, Li H, Pich L. 2016. Technical efficiency analysis of cambodian household's rice production. Global Journal of Human-Social Science Economics 16(3): 33-44.

Ministry A. 2006. Sugarcane plantation Statistics Indonesia. Jakarta: Pusdatin.

Mishra K. 2019. Evaluation of bud chip method for enhancing yield and economics of sugarcane. International Journal of Chemical Studies 7(3): 1726-1729.

Mutenheri E, Kibirige D, Masuku M, Singh A. 2017. Production Efficiency of smallholder Sugarcane Farmers in Swaziland: A Case Study of Ubombo (Lusip \& Poortzicht) Andhhohho (Kddp \& Vuvulane) Farmers. International Journal of Business and Management Invention 6(6): 7280.

Ningsih I. 2014. Efisiensi ekonomis usaha tani kedelai dalam rangka mendukung keanekaragaman pangan (Studi di Desa Mlorah, Kecamatan Rejoso, Kabupaten Nganjuk). HABITAT 25(3): 183-193.

Ningsih I, Dwiastuti R, Suhartini. 2015. Determinant technician efficiency of soybean business. Jurnal Manajemen \& Agribisnis 12(3): 216-225. https:// doi.org/10.17358/JMA.12.3.216..

Ojo S. 2003. Productivity and technical efficiency of poultry egg production in Nigeria. International Journal of Poultry Scientific Information 2(6): 459-464. https://doi.org/10.3923/ ijps.2003.459.464.

Okaye B, Onyenweaku C, Agwu A. 2008. Technical efficiency of small-holder cocoyam farmers in Anambra State Nigeria: implications for agricultural extension policy. Journal of Agricultural Extension 12(1): 10-16. https://doi. org/10.4314/jae.v12i1.47032.

Orewa S, Izekor O. 2012. Technical Efficiency Analysis of Yam Production in Edo State: A Stochastic Frontier Approach. International Journal of Development and Sustainability 1(2): 107-116.

Purnamasari I, Hanani N, Suhartini. 2018. Technical efficiency analysis of sugar cane farming in East Java Indonesia (statistical approach of frontier production functions). Agricultural Socio-
Economics Journal 18(1): 23-29. https://doi. org/10.21776/ub.agrise.2018.018.1.4.

Pusdatin. 2019. Buku Outlook Komoditas Perkebunan Tebu. Jakarta: Pusdatin Kementan.

Rohmatullo, Marimin, Machfud, Nasution M. 2009. Kajian Sistem pengukuran Kinerja Pabrik Gula (Studi Kasus: PG Subang Jawa Barat). Jurnal Manajemen \& Agribisnis 6(1): 15-23.

Samant T. 2017. Bud chip method: A potential technology for sugarcane (Saccharum officinarum) cultivation. Journal of Medicinal Plants Studies 5(3): 355-357.

Singh S, Singh H, Kumari M, Minnatullah M. 2018. Economics analysis of production, resource use efficiency and constraints analysis of sugarcane cultivationineastchamparandistrictofnorthbihar. International Journal of Current Microbiology and Applied Sciences 7(10): 512-519. https:// doi.org/10.20546/ijcmas.2018.710.056.

Stevenson R. 1980. Likelihood function for generalized stochastic frontier estimation. Journal of Econometrics 13(1): 57-66. https://doi. org/10.1016/0304-4076(80)90042-1.

Subiyono. 2014. Thought donation Reaching Triumph National Sugar Industry. Surabaya: PTPN X.

Suek J. 1994. Determinants of Decision Agroforestry Farmers Prefer Traditional Patterns of InterZone in the area of West Timor (Thesis). Bogor: Graduate Program, Bogor Agricultural University.

Sulaiman A et al. 2019. Increasing Sugar Production in Indonesia through land suitability analysis and sugar mill restructuring. Land 8(1): 1-7. https:// doi.org/10.3390/land8040061.

Supaporn P. 2015. Determinants of technical efficiency of sugarcane production among small holder farmers in Lao PDR. American Journal of Applied Sciences. American Journal of Applied Science 12(9): 644-649. https://doi.org/10.3844/ ajassp.2015.644.649.

Susilowati S, Tinaprilla N. 2012. Efficiency analysis farm sugarcane in East Java. Littri Journal 18(4): 162-172.

Vilano R, Fleming. 2006. Technical inefficiency and production risk in rice farming: evidence from central Luzon, Pilipina. Asian Economic Journal 20(1): 29-49. https://doi.org/10.1111/j.14678381.2006.00223.x. 